\title{
The determinants of Islamic social reporting disclosure and its impact on the profitability of sharia banks
}

\author{
Muhammad Sultan Mubarok ${ }^{1}$ \\ IAIN Pekalongan, Jawa Tengah, Indonesia
}

\begin{abstract}
Purpose - This study aims to determine of disclosure level of Islamic Social Reporting (ISR) and its impact on profitability at Sharia Commercial Bank in Indonesia.
\end{abstract}

Method - This study uses Good Corporate Governance (GCG), which is proxied with self-assessment, number of commissioners, and number of Sharia Supervisory Board (DPS), financial is proxied with company size, company age, DER, Social Cost, BOPO, FDR, and NPF. Profitability is proxied with ROA and ROE. The sampling technique used a purposive sampling method. There are 12 Sharia Banks that meet the criteria of the study sample period 2013-2017.

The result - The results showed that: first, GCG hurt ISR. Second, financial factors have a positive effect on ISR. Third, GCG negative affects profitability; the greater the number of commissioners and DPS will have an impact on the material costs of the Bank. Fourth, financial factors have a positive effect on profitability. Fifth, ISR hurts profitability. Sixth, ISR mediates the relationship between GCG and financial factors with profitability.

Implication - This study helps sharia banks to maintain Islamic Social Reporting as a tool to get stakeholders' trust

Originality - This study uses a corporate social responsibility report, which also presents the aspect of religiosity.

Keywords: Islamic social reporting; good corporate governance; financial; profitability; sharia banks

1.Author correspondence: Muhammad Sultan Mubarok, muhammad.sultan.mubarok@iainpekalongan.ac.id, IAIN Pekalongan, Jl. Kusuma Bangsa No.9, Panjang Baru, Kec. Pekalongan Utara, Kota Pekalongan, Jawa Tengah 51141 


\section{Introduction}

The development of Corporate Social Responsibility (CSR) practices in Indonesia is supported by the government. In line with the issuance of JIEMB | 138 regulations concerning CSR practice obligations set out in Law Number 25 of 2007 concerning Foreign Investment, that investors significant to carry out social responsibility. The responsibility in question is inherent in every investment company to continue to create relationships that are harmonious, balanced, and by the environment, values, norms, and culture of the local community. Then Law Number 40 of 2007 concerning Limited Liability Companies in Article 66 states that annual reports must contain some information, one of which is the report on the implementation of social and environmental responsibility.

So far, the measurement of CSR disclosure in sharia institutions still mostly refers to the Global Reporting Initiative Index (Haniffa, 2002: 130). Even though the disclosure of social activities in sharia business entities requires the concept of sharia-based accountability reports. Nevertheless, gradually, it also emerged as an empirical phenomenon such as the concept of sharia-based accountability, Islamic Social Reporting (ISR). ISR is one way to provide full disclosure in an Islamic context. (Othman, 2009)

In Indonesia, disclosure (disclosure) in Islamic banks, in general, has been accommodated in the Statement of Financial Accounting Standards. Namely, PSAK No. 101 of 2006 concerning the presentation of Islamic financial statements. However, this PSAK applies only to financial statements and does not apply to other information presented in annual reports. So there are variations because there are no specific standards that can be used as guidelines for the uniformity of the presentation of the report, both from the theme disclosed, the level of disclosure, location, or place of disclosure in the annual report, and the type of disclosure.

From the outset, the ISR is expected to give birth to accounting concepts and practices that are following Islamic law. The instrument contributes to business progress that is more honest and fair. Therefore, by preparing the 
concept of social accountability will encourage the fulfillment of public needs for information based on sharia principles. The concept of social accountability aims to meet the public's need for information. In the context of Islam, the public has the right to know various information about organizational activities. This is done to see whether the company continues to carry out its activities according to sharia and achieve the stated goals. One way to provide full disclosure in an Islamic context is by applying ISR. (Othman, 2009)

ISR was first put forward by Haniffa (2009), then developed extensively by Othman et al. (2009), specifically in Malaysia. According to Haniffa, there are limitations in conventional social reports, so he put forward an ISR conceptual framework based on Islamic sharia provisions. This conceptual framework not only helps Muslim decision-makers but also helps companies carry out activities and reporting by sharia provisions.

Based on the results of the 2016 Global Islamic Finance Report (GIFR) assessment, Indonesia is included in a country that has quite a good potential with a ranking of sixth in the development of the Islamic financial industry after Malaysia, Iran, Saudi Arabia, the United Arab Emirates, and Kuwait. The rapid development of LKS is not followed by clarity on the concept of CSR disclosure practice criteria in Islamic financial institutions (Yasir Yusuf, 2017). Though this disclosure is expected to be able to present a dimension of religiosity in annual reporting to benefit Muslim stakeholders. Therefore, we need a guideline to measure social responsibility reports that also present aspects of religiosity in sharia-compliant annual reports (Othman, 2009).

The disclosure of sharia business entity annual reports is entirely accountable. However, the assessment score using the ISR index is still not a single Islamic banking that has reached the full figure. This is also reinforced by CSR disclosure data at Islamic Commercial Banks in Indonesia based on the ISR Index 2013-2017 which has an average value that relatively rises each year. There are still a number of BUSs that have an average ISR disclosure value that is still minimal. Data on CSR disclosure fluctuations at Islamic Commercial Banks in Indonesia in Table 1 as follows: 
Muhammad Sultan Mubarok

Table 1. Level of disclosure of Islamic social reporting (ISR) 2013-2017

\begin{tabular}{lllllll}
\hline No & \multicolumn{7}{c}{ Name of the company } & \multicolumn{5}{c}{ Year ((in \%) } \\
& & 2013 & 2014 & 2015 & 2016 & 2017 \\
\hline 1 & Bank Muamalat Indonesia & 71.67 & 75.00 & 78.33 & 80.00 & 88.33 \\
2 & Bank Syariah Mandiri & 78.33 & 68.33 & 80.00 & 80.00 & 83.33 \\
3 & Bank Bank Victoria Syariah & 45.00 & 46.66 & 56.66 & 58.33 & 73.33 \\
4 & Bank BRI Syariah & 53.33 & 61.66 & 66.66 & 73.33 & 90.00 \\
5 & Bank Jabar Banten Syariah & 60.00 & 65.00 & 65.00 & 63.33 & 68.33 \\
6 & Bank Bni Syariah & 66.67 & 66.67 & 70.00 & 71.67 & 81.67 \\
7 & Bank Mega Syariah & 45.00 & 53.33 & 60.00 & 61.67 & 78.33 \\
8 & Bank Panin Syariah & 60.00 & 60.00 & 63.33 & 71.67 & 71.67 \\
9 & Bank Syariah Bukopin & 61.67 & 63.33 & 70.00 & 71.67 & 73.33 \\
10 & Bank BCA Syariah & 53.33 & 65.00 & 70.00 & 70.00 & 75.00 \\
11 & Maybank Syariah Indonesia & 50.00 & 53.33 & 60.00 & 63.33 & 68.33 \\
12 & Bank Tabungan Pensiun Nasional & 51.67 & 65.00 & 65.00 & 63.33 & 66.67 \\
& Syariah & & & & & \\
\hline
\end{tabular}

This study analyzes the broad determinants of Islamic Social Reporting disclosure in Islamic Banks, where the ISR is expected to be able to present a dimension of religiosity in annual reporting to benefit Muslim stakeholders (Othman, 2009: 138). In line with signaling theory, ISR disclosure is one way to send positive signals to stakeholders and markets about the company's prospects (Cheng and Yulius, 2011: 24-36). So that the disclosure of this ISR has an essential role in the value of the company and has an impact on profitability. Thus, the objectives of this study are: first, to analyze the effect of Good Corporate Governance (GCG) on ISR. Second, analyze the influence of financial factors on ISR. Third, analyze the effect of Good Corporate Governance (GCG) on profitability. Fourth, analyze the effect of financial factors on profitability. Fifth, analyze the effect of ISR on profitability. Finally, analyze the influence of financial factors, GCG on profitability by ISR mediation.

\section{Literature review}

Islamic Social Reporting (ISR) is one way to assess sharia corporate social responsibility reporting. According to Haniffa, ISR is an extension of social reporting that includes not only the expectations of the board of directors but also the fulfillment of a spiritual perspective. ISR has two main objectives, first as accountability to Allah SWT and the community. Second to increase the 
transparency of business activities by providing relevant information and by needs. Also, the ISR index emphasizes social justice related to reporting on the environment, minority interests, and employees (Haniffa, 2002).

According to Bayu Tri (2017), ISR is social reporting that involves not only holistic expectations from the community but also a spiritual perspective. The ISR index in this study is calculated with the following indicators:

Tabel 2. Islamic social reporting index (ISR)

\begin{tabular}{|c|c|c|c|}
\hline No & Items of ISR Disclosure & Score & Source \\
\hline A. & Funding and Investment & 6 & \\
\hline 1 & Activities with interest & 1 & $\begin{array}{l}\text { Haniffa (2002) Othman et al. } \\
\text { (2009) }\end{array}$ \\
\hline 2 & $\begin{array}{l}\text { Activities with Gharar (hedging, future on } \\
\text { delivery trading/margin trading, arbitrage } \\
\text { spot or forward, short selling, pure swap, } \\
\text { warrant) }\end{array}$ & 1 & $\begin{array}{l}\text { Haniffa (2002) Othman et al. } \\
\text { (2009) }\end{array}$ \\
\hline 3 & Alms (amount and distribution) & 1 & $\begin{array}{l}\text { Haniffa (2002) Othman et al. } \\
\text { (2009) }\end{array}$ \\
\hline 4 & $\begin{array}{l}\text { Policy for late payment of receivables and } \\
\text { write-off of uncollectible accounts }\end{array}$ & 1 & Othman et al. (2009) \\
\hline 5 & Investment activity (generally) & 1 & Haniffa dan Hudaib (2007) \\
\hline 6 & Funding project (generally) & 1 & Haniffa dan Hudaib (2007) \\
\hline B. & Product and Service & 3 & \\
\hline 7 & $\begin{array}{l}\text { DPS statement on the halal status of new } \\
\text { products and services }\end{array}$ & 1 & Haniffa dan Hudaib (2007) \\
\hline 8 & Types and definition of each product & 1 & Haniffa dan Hudaib (2007) \\
\hline 9 & $\begin{array}{l}\text { Services for customer complaints (form, } \\
\text { number of complaints and resolution) }\end{array}$ & 1 & Haniffa dan Hudaib (2007) \\
\hline C. & Employees & 13 & \\
\hline 10 & Amount of employee & 1 & Haniffa dan Hudaib (2007) \\
\hline 11 & Working hour & 1 & $\begin{array}{l}\text { Haniffa (2002) Othman et al. } \\
\text { (2009) }\end{array}$ \\
\hline 12 & Holiday & 1 & $\begin{array}{l}\text { Haniffa (2002) Othman et al. } \\
\text { (2009) }\end{array}$ \\
\hline 13 & Employee incentives & 1 & $\begin{array}{l}\text { Haniffa (2002) Othman et al. } \\
\text { (2009) }\end{array}$ \\
\hline 14 & Remuneration Policy & 1 & Othman et al. (2009) \\
\hline 15 & Training and education of the employee & 1 & $\begin{array}{l}\text { Haniffa (2002) Othman et al. } \\
\text { (2009) }\end{array}$ \\
\hline 16 & Equal opportunities for all employees & 1 & Othman et al. (2009) \\
\hline 17 & Appreciation for outstanding employees & 1 & Haniffa dan Hudaib (2007) \\
\hline
\end{tabular}


Muhammad Sultan Mubarok

\begin{tabular}{|c|c|c|c|}
\hline No & Items of ISR Disclosure & Score & Source \\
\hline 18 & Employee health and safety & 1 & Othman et al. (2009) \\
\hline 19 & Employee involvement in the company & 1 & Othman et al. (2009) \\
\hline 20 & Adequate place of worship & 1 & Othman et al. (2009) \\
\hline 21 & Time of worship/religious activities & 1 & Othman et al. (2009) \\
\hline 22 & Employee welfare & 1 & Haniffa dan Hudaib (2007) \\
\hline D. & Public & 11 & \\
\hline 23 & Alms/donations (Amounts and Distribution) & 1 & $\begin{array}{l}\text { Haniffa (2002) Othman et al. } \\
\text { (2009) }\end{array}$ \\
\hline 24 & Waqf (type and distribution) & 1 & Haniffa (2002) \\
\hline 25 & $\begin{array}{l}\text { Good card Hasan / loan (Amount and } \\
\text { Distribution) }\end{array}$ & 1 & Haniffa (2002) \\
\hline 26 & Employee volunteers & 1 & Othman et al. (2009) \\
\hline 27 & Providing school scholarships & 1 & Othman et al. (2009) \\
\hline 28 & Empowerment of graduates' work & 1 & Othman et al. (2009) \\
\hline 29 & $\begin{array}{l}\text { school / lecture (internship or field work } \\
\text { practice) }\end{array}$ & 1 & Othman et al (2009) \\
\hline 30 & Youth development & 1 & Othman et al. (2009) \\
\hline 31 & Improving the quality of life of the poor & 1 & Othman et al. (2009) \\
\hline 32 & Concern for children & 1 & $\begin{array}{l}\text { Haniffa dan Hudaib (2007) } \\
\text { dan Othman et al. (2009) }\end{array}$ \\
\hline 33 & $\begin{array}{l}\text { Charity or social activities (natural disaster } \\
\text { relief, blood donation, mass circumcision, } \\
\text { infrastructure development, etc.) }\end{array}$ & 1 & Othman et al. (2009) \\
\hline 34 & Supporting health activities, & 5 & \\
\hline 35 & $\begin{array}{l}\text { entertainment, sports, culture, education, and } \\
\text { religion }\end{array}$ & 1 & $\begin{array}{l}\text { Haniffa (2002) dan Othman } \\
\text { et al. (2009) }\end{array}$ \\
\hline E. & Environment & 1 & Othman et al. (2009) \\
\hline 36 & Environmental conservation & 1 & Othman et al (2009) \\
\hline 37 & $\begin{array}{l}\text { Activities to reduce the effects of global } \\
\text { warming (pollution minimization, waste } \\
\text { management, clean water management, etc.) }\end{array}$ & 1 & Haniffa dan Hudaib (2007) \\
\hline 38 & Education on the environment & 1 & Othman et al. (2009) \\
\hline 39. & Award in the environmental field & 15 & \\
\hline 40. & Environmental management system & 1 & Othman et al (2009) \\
\hline $\mathrm{F}$ & Corporate governance & 1 & SEBI No12/13/DPbS (2010) \\
\hline 41 & Sharia compliance status (DPS opinion) & 1 & Othman et al. (2009) \\
\hline 42 & Anti-corruption policy & 1 & Othman et al. (2009) \\
\hline 43 & $\begin{array}{l}\text { Implement anti-money laundering and } \\
\text { prevent terrorism funding programs }\end{array}$ & 1 & POJK No. 12/POJK.01/2017 \\
\hline 44 & $\begin{array}{l}\text { Provision of funds for social and political } \\
\text { activities }\end{array}$ & 1 & POJK. No. 55/POJK. 03/2016 \\
\hline 45 & $\begin{array}{l}\text { Use of public accounting services and public } \\
\text { accounting firms }\end{array}$ & 1 & POJK. No. 13/POJK.03/2017 \\
\hline
\end{tabular}

Journal of Islamic Economics, Management, and Business - Vol. 1 No. 1 (2019) 
The determinants of Islamic social reporting disclosure....

\begin{tabular}{|c|c|c|c|}
\hline No & Items of ISR Disclosure & Score & Source \\
\hline 46 & $\begin{array}{l}\text { Implementation of Treasury certificates and } \\
\text { application of market code of ethics }\end{array}$ & 1 & PBI No. 19/5/PBI/2017 \\
\hline 47 & $\begin{array}{l}\text { Submitting foreign customer information } \\
\text { related to taxation }\end{array}$ & 1 & SEOJK No. 16/SEOJK.03/2017 \\
\hline 48 & $\begin{array}{l}\text { Reporting and monitoring of debtor } \\
\text { information through financial information } \\
\text { service systems }\end{array}$ & 1 & POJK No. 18/POJK.03/2017 \\
\hline 49 & National payment gateway & 1 & PBI No. 19/8/PBI/2017 \\
\hline 50 & Blocking Customer Funds & 1 & SEOJK No. 38/SEOJK.01/2017 \\
\hline 51 & Lawsuit & 1 & Othman et al. (2009) \\
\hline 52 & $\begin{array}{l}\text { Details of the name and profile of the board } \\
\text { of commissioners }\end{array}$ & 1 & Othman et al. (2009) \\
\hline 53 & $\begin{array}{l}\text { Performance of commissioners } \\
\text { (implementation of responsibilities and } \\
\text { number of meetings) }\end{array}$ & 1 & Othman et al. (2009) \\
\hline 54 & Board of Commissioners' remuneration & 1 & Othman et al. (2009) \\
\hline 55 & $\begin{array}{l}\text { Details of the names and profiles of the } \\
\text { board of directors }\end{array}$ & 1 & Othman et al. (2009) \\
\hline 56 & $\begin{array}{l}\text { Performance of directors (implementation of } \\
\text { responsibilities and number of meetings) }\end{array}$ & 1 & Othman et al. (2009) \\
\hline 57 & Board of Directors' remuneration & 1 & Othman et al. (2009) \\
\hline 58 & Details of DPS names and profiles & 1 & Othman et al. (2009) \\
\hline 59 & $\begin{array}{l}\text { DPS performance (implementation of } \\
\text { responsibilities and number of meetings) }\end{array}$ & 1 & Othman et al. (2009) \\
\hline \multirow[t]{2}{*}{60} & DPS Remuneration & 1 & Othman et al. (2009) \\
\hline & Total & 60 & \\
\hline
\end{tabular}




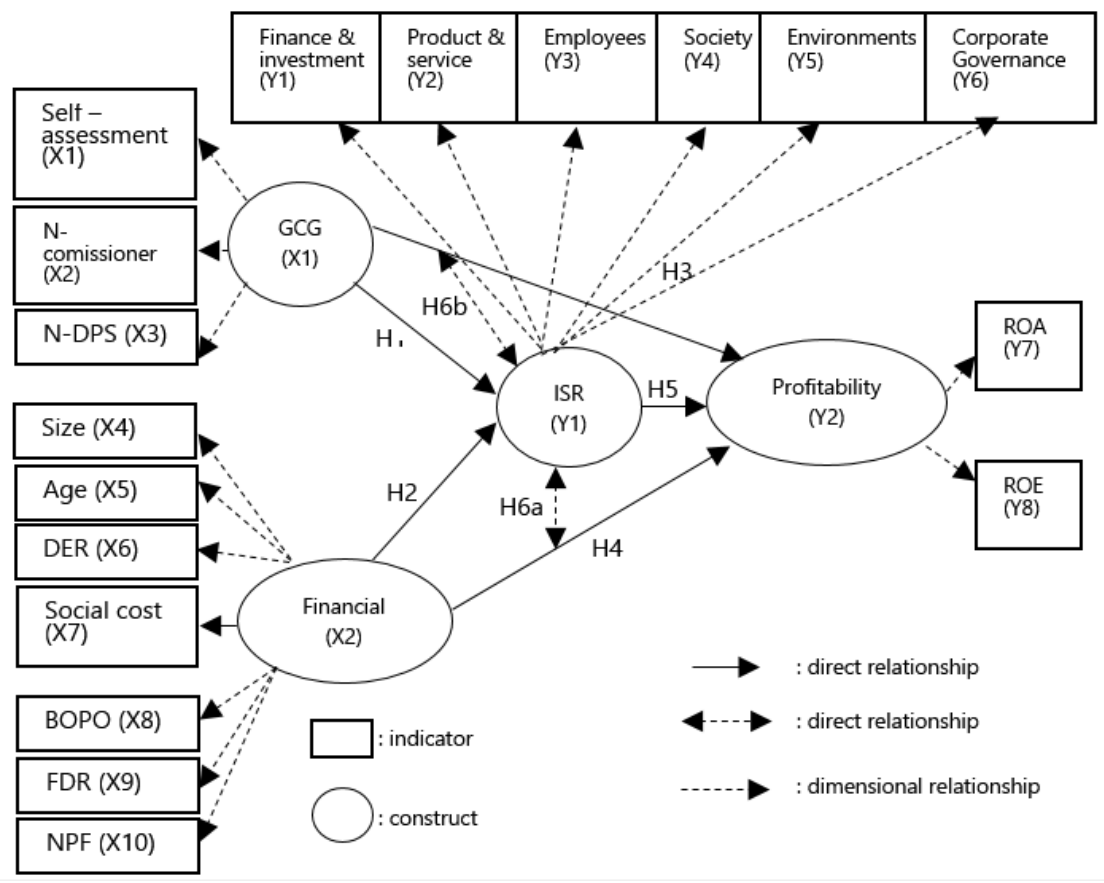

Figure 1. Research Framework

\section{Research methods}

This study uses a quantitative approach to the type of explanatory research. Research that highlights the relationship between research variables and testing hypotheses have been formulated previously. Although the description also contains an explanation, the focus lies in explaining the relationship between variables (Syukron, 2016).

The type of data used in this study is secondary data. Secondary data is a historical data structure about variables that have been collected and collected previously by other parties (Hermawan, 2005). The data is obtained from the Indonesian Banking directory through the official website of each Sharia Commercial Bank. The sampling technique uses purposive sampling method. Purposive sampling is data collection adapted to predetermined criteria (Asnawi and Chandra, 2005). 
A population is an entire object or subject that is in an area and fulfills certain conditions related to the research problem or totality units or individuality within the scope to be examined (Martono, 2012). The population used as objects in this study are consumers of UKM Bandeng Rozal. Based on Solvin's formula, it was found that the number of samples used in the study was 100 respondents.

Data analysis techniques in this study used the Warp PLS software version 5.0, which was run on computer media. Partial Least Square (PLS) is an analysis of variance-based structural equations that can simultaneously conduct measurement model testing as well as structural model testing. The measurement model is used to test the validity and reliability, while the structural model is used to test the causality/hypothesis testing with a prediction model (Abdillah and Jogiyanto, 2009).

Presentation of data using two stages, namely, descriptive statistics and inferential statistics. The descriptive statistical stage is used in explaining the extent of disclosure of Islamic bank ISRs. The inferential statistical stage begins with the measurement of the model (outer model), structural model (inner model), and path coefficient analysis. The outer model determines the specification of the relationship between latent constructs and indicators (Yamin and Heri, 2009: 214). Includes Indicator Reliability and Collinearity. The Inner Model determines the specification of the relationship between latent constructs and other latent constructs (Yamin and Heri, 2009). Moreover, path analysis is used to explain the direction of the relationship between the independent variable and the dependent variable/hypothesis testing.

\section{Results and discussion}

\section{Descriptive analysis of ISR}

Finance and investment theme

Funding and investment themes include six disclosure items. Items that are relatively frequently disclosed are project financing by $100 \%$, investment activities $89.83 \%$, zakat $79.66 \%$, activities containing usury $66.1 \%$, items that 
Muhammad Sultan Mubarok

Tabel 3. Percentage of ISR disclosure funding and investment theme

JIEMB | 146

\begin{tabular}{|c|c|c|}
\hline A. & Funding and Investment & (\%) \\
\hline 1 & Activities with interest & 66,10 \\
\hline 2 & $\begin{array}{l}\text { Activities with Gharar (hedging, future on delivery } \\
\text { trading/margin trading, arbitrage spot or forward, short } \\
\text { selling, pure swap, warrant) }\end{array}$ & 15,25 \\
\hline 3 & Alms (amount and distribution) & 79,66 \\
\hline 4 & $\begin{array}{l}\text { Policy for late payment of receivables and write-off of } \\
\text { uncollectible accounts }\end{array}$ & 47,46 \\
\hline 5 & Investment activity (generally) & 89,83 \\
\hline 6 & Funding project (generally) & 100,00 \\
\hline
\end{tabular}

are relatively rarely disclosed are policies for late payment of receivables and write-off of uncollectible receivables by $47.46 \%$ and activities containing gharar by $15.25 \%$.

\section{Product and service theme}

Product and service themes consist of 3 disclosure items. The items most frequently revealed are the types and definitions of sharia banking products at $94.92 \%$, DPS statements at $91.53 \%$, and services for customer complaints at $76.27 \%$.

Tabel 4. Percentage of ISR disclosure for product and senvice theme

\begin{tabular}{lll}
\hline B. & Product and Service & (\%) \\
\hline 7 & DPS statement on the halal status of new products and services & 91,53 \\
8 & Types and definition of each product & 94,92 \\
9 & $\begin{array}{l}\text { Services for customer complaints (form, number of complaints } \\
\text { and resolution) }\end{array}$ & 76,27 \\
\hline
\end{tabular}

\section{Employee theme}

The theme of employees consists of 13 disclosure items, the items most commonly disclosed by Islamic banking are remuneration policies of $100 \%$, employee education and training $96.61 \%$, number of employees $96.61 \%$, employee benefits $94.92 \%$. Items that are often revealed are the appreciation of 77.97 outstanding employees, $71.19 \%$ of employee health and safety, $71.19 \%$ of employee welfare, opportunity opportunities for employees 
$57.63 \%$. Items that were rarely revealed were worship time $20.34 \%$, employee involvement at the company $18.64 \%$, adequate places of worship $8.47 \%$, and holidays $5.08 \%$. Moreover, what was never revealed was $0 \%$ working hours.

Table 2. Percentage of ISR disclosure BUS employee theme

\begin{tabular}{lll}
\hline C & Employees & $(\%)$ \\
\hline 10 & Amount of employee & 96,61 \\
11 & Working hour & 0,00 \\
12 & Holiday & 5,08 \\
13 & Employee incentives & 94,92 \\
14 & Remuneration Policy & 100,00 \\
15 & Training and education of employees & 96,61 \\
16 & Equal opportunities for all employees & 57,63 \\
17 & Appreciation for outstanding employees & 77,97 \\
18 & Employee health and safety & 71,19 \\
19 & Employee involvement in the company & 18,64 \\
20 & Adequate place of worship & 8,47 \\
21 & Time of worship / religious activities & 20,34 \\
22 & Employee welfare & 71,19 \\
\hline
\end{tabular}

Society theme

The community theme consisted of 11 disclosure items. the items most frequently revealed were alms or donations, improvement in the quality of life of the poor, supporting health activities, etc. by $93.22 \%$, charity or social activities and qardh hasan by $91.53 \%$, items that were often revealed were concern for children amounting to $88.14 \%$, school scholarships by $71.19 \%$, youth development by $57.63 \%$, endowments $45.76 \%$, and items with low disclosure rates were internships by $18.64 \%$ and volunteer employees by 20.34\%.

\section{Environment theme}

The environmental theme consists of 5 disclosure items. Items that are relatively frequently disclosed are environmental conservation by $62.71 \%$ and activities to reduce the effects of global warming by $62.71 \%$. Items that were relatively rarely disclosed were the environmental management system at 
Muhammad Sultan Mubarok

Tabel 6. Percentage of ISR disclosure society theme

\begin{tabular}{llll} 
& D. & Public & $(\%)$ \\
\hline & 23 & Alms / donations (Amounts and Distribution) & 93,22 \\
JIEMB | 148 & 24 & Waqf (type and distribution) & 45,76 \\
& 25 & Good qard hasan / loan (Amount and Distribution) & 91,53 \\
& 26 & Employee volunteers & 20,34 \\
& 27 & Providing school scholarships & 71,19 \\
& 28 & Empowerment of graduates' work & 18,64 \\
& 29 & school / lecture (internship or field work practice) & 57,63 \\
& 30 & Youth development & 93,22 \\
& 31 & Improving the quality of life of the poor & 88,14 \\
& 32 & Concern for children & 91,53 \\
& 33 & Charity or social activities (natural disaster relief, blood donation, & \\
& & mass circumcision, infrastructure development, etc.) & 93,22 \\
\hline
\end{tabular}

$33.90 \%$ and environmental education at $25.42 \%$. Items that have never been revealed are awards in the environmental field.

\section{Corporate governance theme}

The theme of corporate governance consists of 22 disclosure items. Items that are always revealed are share ownership structure, anti-corruption policies, implementation of anti-money laundering and prevention of terrorism funding programs, provision of funds for social and political activities, use of public accounting services and public accounting firms, details of names and profiles of the board of commissioners, commissioners' performance, details of the names and profiles of the board of directors, performance of directors, details of names and profiles of DPS, and DPS performance by $100 \%$, items that are relatively frequently disclosed are sharia compliance status of

Table 3. Percentage of ISR disclosure BUS environment theme

\begin{tabular}{lll}
\hline E. & Environment & $(\%)$ \\
\hline 34 & Environmental conservation & 62,71 \\
35 & Activities to reduce the effects of global warming (pollution & \\
& minimization, waste management, clean water management, etc.) & 62,71 \\
36 & Education on the environment & 25,42 \\
37 & Award in the environmental field & 0,00 \\
38 & Environmental management system & 33,90 \\
\hline
\end{tabular}


$96.61 \%$, income and use of non-halal funds $94.92 \%$, legal cases amounted to $79.66 \%$, remuneration of the board of commissioners $91.53 \%$.

Remuneration of the board of directors and DPS Remuneration amounted to $89.83 \%$. Items that were relatively rarely disclosed were the implementation of Treasury certificates and the application of a market code of ethics of $6.78 \%$,

Table 4. ISR disclosure percentage of Islamic commercial banks in Corporate Governance theme

\begin{tabular}{|c|c|c|}
\hline F. & Corporate governance & (\%) \\
\hline 39 & Sharia compliance status (DPS opinion) & 96,61 \\
\hline 40 & Anti-corruption policy & 94,92 \\
\hline \multirow[t]{2}{*}{41} & Implement anti-money laundering and prevent terrorism funding & \\
\hline & programs & 100,00 \\
\hline 42 & Provision of funds for social and political activities & 100,00 \\
\hline 43 & Use of public accounting services and public accounting firms & 100,00 \\
\hline \multirow[t]{2}{*}{44} & Implementation of Treasury certificates and application of market code & \\
\hline & of ethics & 100,00 \\
\hline 45 & Submitting foreign customer information related to taxation & 100,00 \\
\hline \multirow[t]{2}{*}{46} & Reporting and monitoring of debtor information through financial & \\
\hline & information service systems & 6,78 \\
\hline 47 & National payment gateway & 10,17 \\
\hline 48 & Blocking Customer Funds & 25,42 \\
\hline 49 & Lawsuit & 3,39 \\
\hline 50 & Details of the name and profile of the board of commissioners & 5,08 \\
\hline \multirow[t]{2}{*}{51} & Performance of commissioners (implementation of responsibilities and & \\
\hline & number of meetings) & 79,66 \\
\hline 52 & Board of Commissioners' remuneration & 100,00 \\
\hline 53 & Details of the names and profiles of the board of directors & 100,00 \\
\hline \multirow[t]{2}{*}{54} & Performance of directors (implementation of responsibilities and & \\
\hline & number of meetings) & 91,53 \\
\hline 55 & Board of Directors' remuneration & 100,00 \\
\hline 56 & Details of DPS names and profiles & 100,00 \\
\hline 57 & $\begin{array}{l}\text { DPS performance (implementation of responsibilities and number of } \\
\text { meetings) }\end{array}$ & 89,83 \\
\hline 58 & DPS Remuneration & 100,00 \\
\hline 59 & Corporate governance & 100,00 \\
\hline 60 & Sharia compliance status (DPS opinion) & 89,83 \\
\hline
\end{tabular}


Submission of foreign customer information related to taxation of $10.17 \%$, Reporting and monitoring of debtor information through the financial information service system of $25.42 \%$, Payment gateways Nationally $3.39 \%$, and blocking of customer funds by $5.08 \%$.

\section{Measurement model evaluation (outer model)}

Indicator reliability

Evaluation of the measurement model (outer model) with a formative construct, can be done by looking at its significant weight. If the resulting weight value is significant $(P<0.05)$, then the indicator or item meets the reliability indicator criteria.

\section{Collinearity}

Collinearity is needed in this model because formative constructs are multiple regression relationships from indicators to construct. A standard method used to test Collinearity is by looking at the size of the variance inflation factor (VIF) and its opponent Tolerance. The model is declared good if it has a VIF value $<5$ or $<3.3$.

Because there are indicators that do not meet the Reliability Indicator, it is necessary to retest by eliminating indicators that do not meet the Reliability Indicator, namely DER, BOPO, and NPF indicators.

\section{Measurement model evaluation (inner model)}

$R$-square $\left(R^{2}\right)$

The magnitude of the influence of financial and GCG factors on ISR, financial factors, GCG and ISR on profitability can be seen in the R-Square Coefficient value of 0.04 and 0.27 which means that $4 \%$ of the combination of research variables can affect the level of ISR disclosure while $96 \%$ is influenced by other variables outside research factors, and by $27 \%$ profitability is influenced by a combination of variables selected while other factors outside the research variable influence is $73 \%$.

Q2 predictive relevance 
In this research model, the Q2 value for ISR is 0.252 , which means that the percentage of influence that can be explained by the model is $25.2 \%$, while the

Table 5. The score of the outer mode/ GCG construct, finance, ISR, and profitability

\begin{tabular}{|c|c|c|c|c|c|}
\hline Construct & Indikator & (P-value) & VIF & Weight & Information \\
\hline \multirow{7}{*}{$\begin{array}{l}\text { Financial } \\
\text { factors }\end{array}$} & SIZE & $<0.001$ & 3.328 & 0.399 & $\begin{array}{l}\text { Fulfill Indicator Reliability and } \\
\text { Collinearity }\end{array}$ \\
\hline & AGE & 0.003 & 2.811 & 0.336 & $\begin{array}{l}\text { Fulfill Indicator Reliability and } \\
\text { Collinearity }\end{array}$ \\
\hline & DER & 0.280 & 1.255 & -0.074 & $\begin{array}{l}\text { Not fulfill the Indicator } \\
\text { Reliability }\end{array}$ \\
\hline & BS & 0.016 & 1.356 & 0.259 & $\begin{array}{l}\text { Fulfill Indicator Reliability and } \\
\text { Collinearity }\end{array}$ \\
\hline & BOPO & 0.068 & 1.435 & -0.185 & $\begin{array}{l}\text { Not fulfill the Indicator } \\
\text { Reliability }\end{array}$ \\
\hline & FDR & 0.020 & 1.261 & -0.250 & $\begin{array}{l}\text { Fulfill Indicator Reliability and } \\
\text { Collinearity }\end{array}$ \\
\hline & NPF & 0.411 & 1.362 & -0.029 & $\begin{array}{l}\text { Not fulfill the Indicator } \\
\text { Reliability }\end{array}$ \\
\hline \multirow{3}{*}{ GCG } & N_DPS & $<0.001$ & 1.331 & 0.555 & $\begin{array}{l}\text { Fulfill Indicator Reliability and } \\
\text { Collinearity }\end{array}$ \\
\hline & N_KMSRS & $<0.001$ & 1.321 & 0.547 & $\begin{array}{l}\text { Fulfill Indicator Reliability and } \\
\text { Collinearity }\end{array}$ \\
\hline & SELF_ASS & 0.041 & 1.016 & 0.214 & $\begin{array}{l}\text { Fulfill Indicator Reliability and } \\
\text { Collinearity }\end{array}$ \\
\hline \multirow{6}{*}{ ISRIS } & Finance & 0.028 & 1.489 & 0.235 & $\begin{array}{l}\text { Fulfill Indicator Reliability and } \\
\text { Collinearity }\end{array}$ \\
\hline & Product & 0.105 & 1.523 & 0.156 & $\begin{array}{l}\text { Fulfill Indicator Reliability and } \\
\text { Collinearity }\end{array}$ \\
\hline & Employee & 0.025 & 1.654 & 0.240 & $\begin{array}{l}\text { Fulfill Indicator Reliability and } \\
\text { Collinearity }\end{array}$ \\
\hline & Society & 0.005 & 1.811 & 0.307 & $\begin{array}{l}\text { Fulfill Indicator Reliability and } \\
\text { Collinearity }\end{array}$ \\
\hline & $\begin{array}{l}\text { Environm } \\
\text { ent }\end{array}$ & 0.008 & 1.613 & 0.289 & $\begin{array}{l}\text { Fulfill Indicator Reliability and } \\
\text { Collinearity }\end{array}$ \\
\hline & $\begin{array}{l}\text { Corporat } \\
\text { e }\end{array}$ & 0.019 & 1.738 & 0.253 & $\begin{array}{l}\text { Fulfill Indicator Reliability and } \\
\text { Collinearity }\end{array}$ \\
\hline \multirow{2}{*}{ Profitability } & ROA & $<0.001$ & 1.153 & 0.605 & $\begin{array}{l}\text { Fulfill Indicator Reliability and } \\
\text { Collinearity } y\end{array}$ \\
\hline & ROE & $<0.001$ & 1.153 & 0.605 & $\begin{array}{l}\text { Fulfill Indicator Reliability and } \\
\text { Collinearity }\end{array}$ \\
\hline
\end{tabular}


Muhammad Sultan Mubarok

remaining $74.8 \%$ is influenced by other factors outside the research model. Moreover, Q2 for profitability is 0.243 which means that the percentage of influence that can be explained by the model is $24.3 \%$, while the remaining $75.7 \%$ is influenced by other factors outside the research model.

$A P C, A R S$, dan AARS

APC, ARS, and AARS are used to measure the average path coefficient, Rsquare and Adjusted R-square values generated in the model. APC, ARS, and AARS values are $<0.001,0.05$, and 0.008 . These values $<0.05$ so that the model is fit or feasible.

Table 6. General SEM analysis result

\begin{tabular}{|c|c|c|}
\hline & Index & Information \\
\hline \multirow[t]{2}{*}{ R Square } & ISR $\rightarrow 0.040$ & ISR $=$ weak $(\leq 0.25)$ \\
\hline & PROFIT $\rightarrow 0.27$ & PROFIT $=$ moderate $(\leq 0.45)$ \\
\hline \multirow[t]{2}{*}{ Adjusted $R^{2}$} & ISR $\rightarrow 0.006$ & ISR $=$ weak $(\leq 0.25)$ \\
\hline & PROFIT $\rightarrow 0.226$ & PROFIT $=$ moderate $(\leq 0.45)$ \\
\hline \multirow{2}{*}{$\begin{array}{l}\text { Q2 predictive } \\
\text { relevance }\end{array}$} & ISR $\rightarrow 0.252$ & Model has predictive \\
\hline & PROFIT $\rightarrow 0.243$ & relevance $\left(\mathrm{Q}^{2}>0\right)$ \\
\hline \multirow[t]{6}{*}{ Effect size } & GCG $\rightarrow$ ISR 0.095 & Value of size effect \\
\hline & GCG $\rightarrow$ PROFIT 0.074 & $\geq 0.02$ (weak) \\
\hline & FINANCE $\rightarrow$ ISR 0.135 & $\geq 0.15$ (medium) \\
\hline & FINANCE $\rightarrow$ PROFIT & $\geq 0.35$ (large) \\
\hline & 0.108 & \\
\hline & ISR $\rightarrow$ PROFIT 0.084 & \\
\hline \multirow[t]{3}{*}{ APC, ARS, AARS } & $\mathrm{APC} \rightarrow \mathrm{P}=<0.001$ & Acceptable \\
\hline & $A R S \rightarrow P=0.05$ & $(\leq 0.05)$ \\
\hline & AARS $\rightarrow P=0.08$ & \\
\hline \multirow[t]{2}{*}{ AVIF dan AFVIF } & $\mathrm{AVIF} \rightarrow 1.208$ & Acceptable \\
\hline & AFVIF $\rightarrow 2.022$ & $(<3.3)$ \\
\hline Goodness & 0.289 & $\geq 0.1$ (weak) \\
\hline \multirow[t]{2}{*}{ Tenenhaus } & & $\geq 0.25$ (medium) \\
\hline & & $\geq 0.36$ (large) \\
\hline SPR & 0.800 & $\begin{array}{l}\text { Accepted } \\
(\geq 0.7)\end{array}$ \\
\hline RSCR & 0.809 & Accepted $(\geq 0.7)$ \\
\hline NLBCDR & 0.800 & Accepted $(\geq 0.7)$ \\
\hline
\end{tabular}


The determinants of Islamic social reporting disclosure....

\section{AVIF dan AFVIF}

AVIF and AFVIF are two size fit models that are used to test collinearity problems. The results show AVIF and AFVIF values of 1,208 and 2,022, this value $<3.3$ so that the model is not subject to collinearity problems.

The goodness of fit (GOF)

The results showed the Goodness Tenenhaus (GOF) value of 0.289, which means Goodness Of Fit medium model because of $>0.15$.

\section{Hypothesis testing}

Hypothesis testing direct effect model

This test is done by path analysis (path analysis) of the model that has been made, the results of the path coefficients analysis are presented in Table 7. The results of the path coefficient (regression weight) in Table 7, show the results of the research model conducted in this study, accompanied by the coefficient value.

So that it can be seen that the path coefficients of each variable can be entered in the structural model equation as follows:

$$
\begin{aligned}
& \eta 1=-0.242 \xi 1+0.314 \xi 2+\zeta 1 \ldots \ldots . . \\
& \eta 2=-0.381 \xi 1+0.444 \xi 2-0.368 \xi 3+\zeta 2 \ldots \ldots \ldots . . .
\end{aligned}
$$

\begin{tabular}{|c|c|c|c|c|}
\hline $\begin{array}{l}\text { Path Coefficients } \\
\text { Relation between } \\
\text { variables }\end{array}$ & Estimate & P-Value & SE & Conclusion \\
\hline GCG $\rightarrow$ ISR & -0.242 & 0.024 & 0.120 & Accepted \\
\hline FINANCE $\rightarrow$ ISR & 0.314 & 0.005 & 0.116 & Accepted \\
\hline GCG $\rightarrow$ PROFIT & -0.381 & $<0.001$ & 0.114 & Accepted \\
\hline FINANCE $\rightarrow$ PROFIT & 0.444 & $<0.001$ & 0.111 & Accepted \\
\hline ISR $\rightarrow$ PROFIT & -0.368 & 0.001 & 0.114 & Accepted \\
\hline
\end{tabular}

Tabel 7. Full Model Analysis Result

Significant (two-tailed) $P$ value $=0.05$ 
Muhammad Sultan Mubarok

In which:

६1 (Ksi): GCG as first exogen variable (independent)

द2: Financial as second exogen variable (independent)

JIEMB | 154

$\xi 3:$ ISR as the third exogen variable (independent)

$\eta 1:$ ISR as the first endogenous (bound) variable or mediation

१2: Profitability is a pure endogenous (dependent) variable or a second dependent variable

$\zeta 1,2$ (Zeta) : Measurement error of structural equation.

Table 7 above shows the path coefficient value of each variable with the assumption cateris paribus, and then it can be interpreted as follows:

1. The effect of GCG on ISR of -0.242 with a p-value of 0.024 , which means $p$ value $<0.05$ and standard error of 0.120 . This means that if there is an increase in GCG value of 1 unit, it will negatively affect the level of ISR disclosure of 0.242 units.

2. Financial influence on ISR of 0.314 with a $p$-value of 0.005 , which means $p$ value $<0.05$ and a standard error of 0.116 . This means that if there is an increase in the financial value of 1 unit, it will have a positive effect on the level of ISR disclosure of 0.314 units.

3. The effect of GCG on the profitability of $-0,381$ with a p-value of $<0.001$, which means $p$-value $<0.05$ and a standard error of 0.114 . This means that if there is an increase in the value of GCG by 1 unit, it will negatively affect the profitability level of 0.381 units.

4. Financial influence on the profitability of 0.444 with a $p$-value of $<0.001$, which means $p$-value $<0.05$ and a standard error of 0.111 . This means that if there is an increase in the financial value of 1 unit, it will have a positive effect on the level of profitability of 0.444 units.

5. The effect of ISR on the profitability of -0.368 with a $p$-value of 0.001 , which means $p$-value $<0.05$ and standard error of 0.114 . this means that if there 
The determinants of Islamic social reporting disclosure....

is an increase in the value of the ISR of 1 unit it will negatively affect the level of profitability of 0.368 units.

Hypothesis testing indirect effect model (mediation)

The ISR testing procedure as a mediating variable between GCG and financial factors and profitability is as follows (Baron and Kenny, 1986: Hair et al., 2010, Kock, 2011):

1. Estimating the direct effect on profitability (line $c$ )

2. Estimating indirect effects simultaneously with the PLS-SEM Model triangle, namely GCG/financial $\rightarrow$ profitability (path c'), GCG/financial $\rightarrow$ ISR (path a), and ISR $\rightarrow$ profitability (path b).

The mediation effect requirements that must be fulfilled are the path coefficient $\mathrm{c}$ is significant in model (1), and the path coefficient and $\mathrm{b}$ must be significant in model (2). The conclusion of mediation is as follows:

1. If the path coefficient $c$ 'from the estimation results of the model (2) remains significant and does not change $\left(c^{\prime}=c\right)$, then mediation is not supported.

2. If the path coefficient $c$ 'value decreases $\left(c^{\prime}<c\right)$ but it remains significant, then the form of mediation is partial mediation.

3. If the path coefficient $c^{\prime}$ 'falls $\left(c^{\prime}<c\right)$ and becomes insignificant, then the form of mediation is full mediation.

4. The results of testing the mediation model can be seen in Table 8 .

From Table 8, it can be concluded that ISR mediates the relationship between CGC and profitability. This can be seen from the fulfillment of mediation effect requirements; namely, path $c 1, a 1$, and b1, are significant, with coefficient values of $-0.292,-0.242$ and -0.368 , respectively. GCG direct effect coefficient on profitability in a model (1) is -0.292 and significant.

The estimation results of the model (2) show an indirect effect of GCG on profitability (c ') of 0.089 and a total effect of -0.292 so that the Variance Accounted For (VAF) value of $0.089 /-0.292=0.305$ is obtained. This shows 
the form of martial mediation or in other words, ISR partially mediates the influence of GCG with profitability. There are other variables outside the research model that also mediate the relationship between GCG and Profitability.

ISR mediates the relationship between finance and profitability. This can be seen from the fulfillment of the mediation effect requirements, namely, the coefficients c2, a2, and b2 are significant, with coefficients of $0.444,0.314$ and -0.368 , respectively. CGC direct effect coefficient on profitability in the model (1) is 0.444 and significant. The estimation results of the model (2) show the indirect effect of GCG on profitability (c ') of -0.116 and a total effect of 0.328 , so the Variance Accounted For (VAF) value of $-0.116 / 0.328=0.354$ is obtained. This shows the form of martial mediation or in other words, ISR partially mediates the influence of Financial with profitability. There are other variables outside the research model that also mediate the relationship between Financial and Profitability.

\section{Interpretation of result}

Effect of GCG towards ISR

The results showed that GCG has a positive and significant effect on ISR. This can be seen in the results of the acquisition of GCG values of $-0,242$ with

Table 8. The amount of direct, indirect, and total influence of variables GCG, finance, ISR, and profitability.

\begin{tabular}{lllllll}
\hline Path & $\begin{array}{l}\text { Direct Effect } \\
\text { Coefficient }\end{array}$ & $p$-value & $\begin{array}{l}\text { Indirect Effect } \\
\text { Coefficient }\end{array}$ & $p$-value & $\begin{array}{l}\text { Total Effect } \\
\text { Coefficient }\end{array}$ & $p$-value \\
\hline GCG $\rightarrow$ ISR & -0.242 & 0.024 & & & -0.242 & 0.024 \\
FINANCE $\rightarrow$ IS & 0.314 & 0.005 & & & 0.314 & 0.005 \\
R & & & & & & \\
ISR $\rightarrow$ PROFIT & -0.368 & 0.001 & & & -0.368 & 0.001 \\
GCG $\rightarrow$ PROFI & -0.381 & $<0.001$ & 0.089 & 0.161 & -0.292 & 0.008 \\
T & & & & & & \\
FINANCE $\rightarrow P$ & 0.444 & $<0.001$ & -0.116 & 0.098 & 0.328 & 0.003 \\
ROFIT & & & & & & \\
\hline
\end{tabular}


a $p$-value of 0.024 , which means $p$-value $<0.05$. This proves that the null hypothesis (Ho 1) is rejected, and the alternative hypothesis ( $\mathrm{Ha} 1$ ) is accepted.

This shows that the better the value of self-assessment, the number of commissioners, and the number of Sharia Supervisory Boards (DPS) can affect the reduction in the area of ISR disclosure at Islamic commercial banks. Provisions in Indonesia in Law No. 40 of 2007 states that a company whose business activities are related to raising funds / or managing public funds, issues a debt acknowledgment to the public or a Public Company must have at least two members of the Board of Commissioners.

This means that the size of the board of commissioners does not guarantee a better oversight mechanism, because it is not a significant determinant of the effectiveness of supervision of company management. The effectiveness of the supervisory and control mechanism carried out by the Board of Commissioners depends on the values, norms and trust received by an organization. Thus, in order to achieve greater transparency and disclosure of the ISR, the formation of the Board of Commissioners must take into account the composition, ability and integrity of members so that they can perform their supervisory, control, and be able to provide direction to manage properly.

The role of DPS is not yet optimal in the area of ISR disclosure because the duties and authority of DPS are still focused on product approval, calculation and payment of zakat and other operational activities, so that supervision of social responsibility at the level of supervision is deemed insufficient.

The results of this study are not consistent with the results of Intan Gestari's research (2014: 1), concluding that the size of the board of commissioners and the frequency of audit committee meetings have a positive and significant effect on the level of ISR disclosure. Roziq and Herdian (2011) concluded that GCG had a significant positive effect on the disclosure of Corporate Social Responsibility on BUS. Ans Kolk and Pinkse (2009: 15) concluded that GCG could influence the practice of corporate social responsibility disclosure in multinational companies. Khan et.al (2012) found that the attributes of 
Muhammad Sultan Mubarok

corporate governance have an important role in ensuring organizational legitimacy through CSR disclosure.

Effect of financial towards ISR

The results of the study found that financial has a positive and significant influence on ISR. This can be seen in the results of the acquisition of financial value of 0.314 with a $p$-value of 0.005 , which means $p$-value $<0.05$. this proves that the null hypothesis (Ho2) is rejected, and the alternative hypothesis ( $\mathrm{Ha} 2)$ is accepted.

This shows that the higher financial level certainly can increase the increase of ISR disclosure in Islamic commercial banks in Indonesia. This result confirms that the combination of company size (age), company age (age), Social Cost (BS), BOPO, and FDR are good predictors for ISR.

Theoretically, a bigger company will not escape pressure. Operating activities and greater influence on society are considered in shareholder policy. They pay more attention to the social programs they make. So that the disclosure of corporate social responsibility will be more extensive (Achmad: 2011).

The results of this study support agency theory, where agency theory explains that large companies that have greater agency costs will disclose broader information to reduce agency costs (Eddy: 2006).

The results of this study are consistent with the results of research Anita Anggraini (2015) found that size, profitability, leverage proved to have a significant positive effect on the level of disclosure of Islamic Social Reporting (ISR). Tria Karina and Etna Nur (2014) company size and sharia securities have a positive effect on ISR disclosure. Ali Rama (2014) bank size has a significant positive effect on ISR disclosure. Badingatus Solikhah (2016) industry sensitivity and company size can influence CSR disclosure in companies.

Lutfan Dwi (2016) concluded that liquidity and leverage influence the disclosure of ISR. Rubin et al. (2006) concluded that ownership and leverage have a negative relationship with the level of corporate CSR disclosure. Meti 
Puspa (2014) concluded that the higher the allocation of social costs, the broader the disclosure of CSR. Dewi and Ade Sofyan (2017) concluded the results together with all independent variables including bank size, Capital Adequacy Ratio (CAR), Non-Performing Financing (NPF), Return on Assets (ROA), Financing to Deposit Ratio (FDR) have an influence on CSR disclosure.

\section{Effect of GCG towards profitability}

The results showed that GCG has a negative and significant effect on profitability, this can be seen in the results of the acquisition of GCG values to the profitability of -0.381 with a $p$-value of $<0.001$ which means $p$-value $<0.05$. this proves that the null hypothesis ( $\mathrm{Ho} 3$ ) is rejected, and the alternative hypothesis ( $\mathrm{Ha} 3$ ) is accepted. The researcher suspects that the initial GCG factor has a significant positive effect on profitability but in reality, GCG has the opposite effect on profitability.

In Islamic banking, the application of GCG has been regulated by Bank Indonesia through the issuance of Bank Indonesia Regulation (PBI) No. 11/33 / PBI / 2009. This PBI was issued because of the desire of BI to build a healthy and resilient Islamic banking industry as well as an effort to protect the interests of stakeholders and increase compliance with applicable laws and regulations. However, the findings of this study indicate a negative effect on profitability, this is due to the factor of the number of National Sharia Councils or the Number of Commissioners which will have an impact on the size of the remuneration expense ratio (salary) at the Bank itself, the more the number of DPS or Commissioners will reduce the level of profitability of the Bank.

These findings are consistent with research conducted by Yawson (2006) concluding that a large board size results in high managerial costs, which have an impact on decreasing profitability. Dewayanto (2010) and Puspita Sari and Ernawati (2010) concluded that the size of the board of commissioners had a significant negative effect on the financial performance of Islamic banking. 


\section{Result of financial towards profitability}

The results showed that finance has a positive and significant effect on profitability. This can be seen in the results of the acquisition of GCG values to the profitability of 0.444 with a $p$-value of $<0.001$, which means $p$-value $<0.05$. This proves that the null hypothesis $(\mathrm{Ho} 4)$ is rejected, and the alternative hypothesis ( $\mathrm{Ha} 4)$ is accepted.

The size of the company is one measure of the level of success of companies in carrying out business activities. The more successful the company manages its business, the company will experience growth in its business. The size of the company is also a scale that serves to classify the size of the business entity. The greater the business entity, the greater the profit generated.

The age of the company can demonstrate the company's ability to overcome company difficulties that threaten the company's growth and the company's ability to take opportunities in the environment in which it operates. Thus it can be said that the longer a company is established, the more the company can show its existence in its environment, and the more it can increase investor confidence and have an impact on the level of profitability.

The results of this study are consistent with the results of research by Reychard Griha et al. (2014) finding that FDR influences ROA. Yasir and Mahriana (2016) found that NPF, FDR influence ROA. Alindra et al. (2014) found that credit risk, capital and efficiency affect ROA. Palupi and Sri (2015) found BOPO, NPF to influence ROA.

Pupik Damayanti (2012) found that size and CAR affect profitability. Moh. Rifai et al. (2015) found that firm size affects profitability. Yogi and Wayan (2013) concluded that size affected bank profitability. Kamaliah et al. (2009) conclude simultaneously and partial activity ratios, leverage, company size and company age affect profitability. Yunni Rusmawati (2016) concluded that company size and company age affect company profitability. Gilang and 
The determinants of Islamic social reporting disclosure....

Hening (2014) concluded that the higher the age of the company the more profitability will increase and the size of the company will affect profitability.

\section{Result of ISR towards profitability}

The results showed that the ISR has a negative and significant effect on profitability. This can be seen in the results of the acquisition of the ISR value to a profitability of -0.368 with a $p$-value of 0.001 , which means $p$-value $<0.05$. This proves that the null hypothesis ( $\left.\mathrm{Ho}_{5}\right)$ is rejected, and the alternative hypothesis ( $\mathrm{Ha} 5$ ) is accepted. The researcher suspects that initially, the ISR factor had a significant positive effect on profitability but in reality, the ISR had the opposite effect on profitability.

Based on signaling theory, CSR disclosure is one way to send positive signals to stakeholders and the market regarding the company's prospects. This can also be a promotional signal that the company is better than other companies because it cares about the economic, environmental and social impacts of the company's activities (Cheng and Yulius, 2011). This could be due to the more widespread disclosure of ISR to the Bank. The negative impact will increase the burden or social costs so that it can reduce company profits. Another factor that is causing is fluctuation in profitability (ROA and ROE) at Islamic Banks for the 2013-2017 observation period has decreased. So the extent of ISR disclosure has a negative influence on the profitability of Islamic banks. Another factor that causes is the level of inefficiency in Islamic banks is quite high (negative ROA value). This inefficiency is due to the encouragement of the government to develop the Islamic banking industry.

Investors are expected to consider CSR disclosure information in the company's annual report. So that investment decision making is not solely based on profit information. CSR disclosure is also expected to provide additional information other than those already included in accounting income (Syakti and Lundovicus, 2007).

Research findings that show ISR negatively and significantly affect profitability are consistent with research conducted by Kotchen and Jon Jungbien (2011), concluding that when companies do more harm, they also 
get more good, in this case, when more social activities are carried out it will reduce the company's profit.

Hermalin and Weisbach (2011) Conclude that increased disclosure such as JIEMB | 162 a double-edged sword, the first side shows the disclosure of further information can help companies in making better decisions, the second side with the disclosure of information can create additional subsidies and other costs for shareholders.

\section{ISR mediating relationship between CGC and profitability}

This can be seen from the fulfillment of mediation effect requirements; namely, path c1, a1 and b1 are significant, with coefficient values of -0.292 , 0.242 and -0.368 , respectively. CGC direct effect coefficient on profitability in the model (1) is -0.292 and significant. The estimation results of the model (2) show an indirect effect of GCG on profitability (c ') of 0.089 and a total effect of -0.292 so that the Variance Accounted For (VAF) value of $0.089 /-0.292=$ 0.305 is obtained. this shows the form of martial mediation or in other words, ISR partially mediates the influence of GCG with profitability. This proves that the null hypothesis ( $\mathrm{Ho6a}$ ) is rejected, and the alternative hypothesis ( $\mathrm{Ha6a}$ ) is accepted.

ISR mediates the relationship between finance and profitability. This can be seen from the fulfillment of the mediation effect requirements, namely, the coefficients $\mathrm{c}_{2}, \mathrm{a} 2$, and b2 are significant, with coefficients of $0.444,0.314$ and -0.368 , respectively. CGC direct effect coefficient on profitability in the model (1) is 0.444 and significant. The estimation results of the model (2) show the indirect effect of GCG on profitability (c ') of -0.116 and a total effect of 0.328 , so the Variance Accounted For (VAF) value of $-0.116 / 0.328=0.354$ is obtained. This shows the form of martial mediation or in other words, ISR partially mediates the influence of Financial with profitability. This proves that the null hypothesis (Ho6b) is rejected, and the alternative hypothesis ( $\mathrm{Ha} 6 \mathrm{~b})$ is accepted.

Providing adequate, accurate, and timely information to stakeholders must be carried out by the company in order to provide a positive signal and 
be considered transparent. Adequate disclosure is needed by investors to make decisions about the risks and benefits of their investments (Adrian, 2011).

These findings are consistent with the research of Sigit and Afiyah (2009), concluding that CSR disclosure can moderate the relationship of financial performance to firm value. Dwinita Aryani (2012) concluded that company performance has a direct effect on firm value, but it does not affect indirectly through CSR variables as intervening.

Andreas et al. (2016) concluded that CSR disclosure has a direct effect on investor reaction and mediates the relationship between company size, media exposure, industry sensitivity and investor reaction. CSR disclosure is an essential factor for investors to manage their investments. Ali Raza et. al (2012) concluded that there is a positive relationship between CSR and CFP using ROA and ROE.

\section{Conclusion}

The result of this research show that:

1. Good Corporate Governance (GCG) has a significant negative effect on Islamic Social Reporting (ISR) with a coefficient of -0.224 and a significance of 0.024 . This shows that the higher level of GCG can influence the reduction of ISR disclosure in Islamic commercial banks in Indonesia. This means that the size of the board of commissioners does not guarantee a better oversight mechanism, because it is not a major determinant of the effectiveness of supervision of company management.

2. Financial factors have a significant positive effect on Islamic Social Reporting (ISR) with a coefficient value of 0.314 and a significance of 0.005 . This shows that the higher financial level certainly can increase the increase of ISR disclosure in Islamic commercial banks in Indonesia. Larger companies will not escape pressure. Operating activities and greater influence on society are considered in shareholder policy. They pay more 
attention to the social programs they make. So that the disclosure of ISR will be more extensive.

3. Good Corporate Governance (GCG) has a significant negative effect on profitability with a coefficient of -0.381 and a significance of $<0.001$. This shows that the higher implementation of GCG can reduce the level of profitability at Islamic commercial banks in Indonesia. This decline in profitability is due to the greater number of National Sharia Councils or the Number of Commissioners which will have an impact on the size of the remuneration expense ratio (salary) at the Bank itself, the greater the salary burden will reduce the profitability of the Bank.

4. Financial factors have a significant positive effect on profitability with a coefficient of 0.444 and a significance of $<0.001$. This shows that the higher the financial factors can increase the level of profitability of Islamic commercial banks in Indonesia. The financial factor is a scale that serves to classify the size of the business entity. The greater the business entity, the greater the profit generated. In addition, the financial factor can show the existence in the environment, and can increase the confidence of stakeholders that have an impact on the level of profitability.

5. Islamic Social Reporting (ISR) has a significant negative effect on profitability with a coefficient value of -0.368 and a significance of 0.001 . This shows that the higher the Islamic Social Reporting (ISR) can reduce the level of profitability at Islamic commercial banks in Indonesia. This decrease in profitability can be caused by the more widespread disclosure of ISR to the Bank, the negative impact will increase the burden or social costs so that it can reduce the company's profit. Another factor that is causing is fluctuation in profitability (ROA and ROE) at Islamic Banks for the 20132017 observation period has decreased.

6. Islamic Social Reporting (ISR) mediates the relationship between financial factors and profitability with a Variance Accounted For (VAF) value of 0.305 (30.5\%) and significant on direct effects and indirect effects. And ISR mediates the relationship between Good Corporate Governance (GCG) 
with profitability with a Variance Accounted For (VAF) value of 0.328 (32.8\%) and significant for direct effects and indirect effects. This shows that the higher the level of Islamic Social Reporting (ISR) disclosure at Islamic Commercial Banks, then it can strengthen the relationship between Good Corporate Governance (GCG) and financial factors with profitability. The level of disclosure of Islamic Social Reporting (ISR) is one important consideration for stakeholders in making better decisions.

From the conclusions and limitations in this study, the suggestions given to further research are:

1. Developing formative indicators for GCG variables in future research can add DPS competency indicators, number of DPS meetings, commissioners 'competencies, number of commissioners' meetings and others.

2. Changing the object of research in order to obtain the effect of ISR on better profitability. As an alternative, we can use the object of research in companies listed on Sharia Securities List (DES) and the Jakarta Islamic Index (JII).

3. Subjectivity is a common thing encountered in research with descriptive statistical methods. Thus to reduce the level of error can discuss with researchers who discuss the same theme.

4. The next researcher is expected to be able to develop ISR items in more detail and comprehensively.

The results of this study prove that the level of ISR disclosure at Islamic Commercial Banks in Indonesia for the period 2013-2017 is not yet optimal. This is less consistent when compared to the increasing number of BUS, UUS or other Islamic financial institutions in Indonesia. Therefore it is necessary to have a clear guideline on the disclosure of Islamic Social Reporting of Islamic Commercial Banks in Indonesia.

This research also proves that Islamic social reporting is able to be a mechanism for companies to maintain good relations and stakeholder trust. This confirms the opinion stating that the disclosure of sharia-based social information is also a stakeholder's need for non-financial performance 
Muhammad Sultan Mubarok

information, as a basis for evaluating and evaluating management performance. Thus the disclosure of Islamic social reporting is a medium of communication, a form of commitment, corporate responsibility in maintaining good relations and trust on an ongoing basis to gain support from stakeholders to realize goals and increase profitability.

ISR can strengthen the relationship between financial factors on profitability. This can be used as a reference for Islamic banks to be more complex and detailed in providing information about ISR so that it will have an impact on the level of profitability.

This research has methodological implications, especially in assessing ISR index scores at Islamic Commercial Banks, this index was prepared and adjusted to the latest legislation (amendment) that applies in 2017 in Indonesia. Previous researchers have not widely used this approach. Thus, this study adds to the realm of measuring the level of ISR disclosure variables that have been studied.

\section{References}

Abdillah dan Jogiyanto, Konsep dan Aplikasi PLS (Partial Least Square) untuk penelitian Empiris, Yogyakarta: Badan Penerbit Fakultas Ekonomi, 2009

Adrian Sutedi, Good Corporate Governance, (Jakarta: Sinar Grafika, 2009)

Alhamda, Syukron. "Buku Ajar Metlit dan Statistik". Yogyakarta: Deepublish., 2016. Edisi Pertama. Cet. Pertama

Andreas Tan et.al., "Determinants of Corporate Social Responsibility Disclosure and Investor Reaction", Internasional Journal of Economics and Financial Issues, Vol. 6, (2016) h. 15. diakses 28 Januari 2018. https:// www. st-andrews. ac.uk/media/ csear/ discussion-papers/CSEAR_dpsfinance-dofinmar.pdf

Anggraini, Anit. "Faktor Financial Non Financial Dan Tingkat Pengungkapan Islamic Social Reporting (ISR)" (2015): Jurnal Akuntansi dan Keuangan Islam Vol. 2, No. 2 (2015). Sekolah Tinggi Ekonomi Islam SEBI. diakses 07 November 2017 
The determinants of Islamic social reporting disclosure....

Asnawi, Said Kelana dan Chandra Wijaya. "Riset Keuangan: Pengujianpengujian Empiris". Jakarta: Gremedia Pustaka Utama, 2005.

Asyhari, Lutfan Dwi. "Pengaruh Corporate Governance Terhadap Pengungkapan Islamic Social Reporting Pada Bank Umum Syariah di Indonesia", (2016): Jurnal Ilmiah. Fakultas Ekonomi, Universitas Muhammadiyah Yogyakarta. diakses 07 November 2017

Badjuri, Achmad. Faktor-Faktor Fundamental, Mekanisme Corporate Governance,Pengungkapan Corporate Social Responsibility (Csr) Perusahaan Manufaktur Dan Sumber Daya Alam di IndonesiaCorporate Governance Mechanism, Fundamental Factors, CorporateSocial Responsibility (Csr) disclosure Of A Natural Resource AndManufacture Company In Indonesian. dinamika Keuangan dan Perbankan, Vol. 3, No. 1 , 2011.http://

WWW. unisbank.ac.id/ojs/index.php/fe1/article/view/2064/732

Cheng, Megawati dan YuliusJogiChristiawan, Pengaruh Pengungkapan Corporate Social Responsibility Terhadap Abnormal Return, Jurnal Akuntansi Dan Keuangan, Vol. 13, No. 1, 2011. http://jurnal akuntansi. petra.ac.id/ index. php/ aku/ article/view/18236/18104

Damayanti, Pupik. Analisis Pengaruh Ukuran (Size), Capital Adequacy Ratio (CAR), Pertumbuhan Deposit, Loan To Deposit Rasio (LDR), Terhadap Profitabilitas Perbankan Go Public di Indonesia tahun 2005 - 2009: Studi empiris perusahaan perbankan Yang Terdaftar diBei, ( Jurnal IImu Manajemen dan Akuntansi Terapan JIMAT, STIETotalwin Semarang, Vol. 3 No. 2, 2012). http://download. portalgaruda.org/ article. php? article $=142360 \& \mathrm{val}=5446$

Dwinita Aryani, "Kajian Kinerja Keuangan Dan Corporate Social Responsibility Terhadap Good Corporate Governance Dan Nilai Perusahaan"Seminar Nasional dan Call For Papers, (2012). Issn 978-979-3649-65-8

Filia Puspitasari dan Endang Ernawati, "pengaruh mekanisme corporate governance terhadap kinerja keuangan badan usaha", Jurnal Manajemen Teori dan Terapan, Vol. 3, No2. 2010

Gestari R.D, Intan. "Pengaruh Good Corporate Governance Dan Profitabilitas Terhadap Pengungkapan Islamic Social Reporting Pada Bank Umum Syariah di Indonesia". (2014) : Skripsi. Fakultas Ekonomika Dan Bisnis Program Studi Akuntansi Universitas Muhammadiyah Surakarta. diakses 07 November 2017 
Muhammad Sultan Mubarok

Gilang Suryamis Dan Hening Widi Oetomo, "Pengaruh Laverage, Umur Perusahaan Dan Ukuran Perusahaan Terhadap Profitabilitas", STIESIA Surabaya, Jurnal IImu \& Riset Manjemen Vol. 3 No. 9. 2014

Global Islamic Finance Report (GIFR) adalah publikasi yang menyediakan analisis yang diberikan oleh para pelaku industri keuangan Islam global, yang dikeluarkan oleh BMB Islamic (lembaga konsultan bisnis dan manajemen) terkemuka yang berbasis di London. di akses pada 14 Maret 2018, http://www.gifr.net/

Global Islamic Finance Report (GIFR), Islamic Finance Country Index, https://ceif.iba.edu.pk/pdf/GIFR-IslamicFinanceCountrylndex2016.pdf

Griha, Reychard dkk., Analisis Faktor Rasio CAMEL terhadap Profitabilitas Bank Perkreditan Rakyat di Pekanbaru tahun 2008-2012, ( JOMFekon, Universitas Pekanbaru, Vol. 1. No. 2, 2014). https://jom.unri.ac.id/index.php/JOMFEKON/article/viewFile/4368/425 2

Haniffa, R. \&Hudaib, M. J Bus Ethics (2007)" Exploring the Ethical Identity of Islamic Banks via Communication in Annual Reports "76: 97. https://doi.org/10.1007/s10551-006-9272-5

Haniffa, R. (2002). Social Reporting Disclosure: An Islamic Perspective. Indonesian Management and Accounting Research.

Hermalin, Benjamin E. and Weisbach, Michael S., Information Disclosure and Corporate Governance (January 30, 2011). Fisher College of Business Working Paper No. 2008-03-016; Journal of Finance, Forthcoming; Charles A. Dice Center Working Paper No. 2008-17. Available at SSRN: https://ssrn.com/abstract=1082513

Hermawan, Asep. "Penelitian Bisnis Pradigma Kuantitatif ". Jakarta: PtGrasindo, 2005.

Hermawan, Sigit; Maf'ulah, AfiyahNurul. Pengaruh Kinerja Keuangan Terhadap Nilai Perusahaan Dengan Pengungkapan Corporate Social Responsibility Sebagai Variabel Pemoderasi. Jurnal dinamika Akuntansi, [S.L.], V. 6, N. 2, P. 103-118, Sep. 2014. Issn 2502-6224. Available At: $<$ Https:// Journal. Unnes.Ac.ld/ Nju/Index.Php/Jda/Article/View/3250>. Date Accessed: 23 Feb. 2018. Doi:Http:// Dx. Doi. Org/10.15294/Jda.V6i2.3250

Indah, MetiPuspa ."Pengaruh Biaya Sosial Dan Pengungkapan Corporate Social Responsibility Terhadap Kinerja Keuangan Dengan Kinerja Sosial 
The determinants of Islamic social reporting disclosure....

Sebagai Variabel Mediasi".(2014) : Jurnal Akuntasi dan Manajemen Vol.25, No 2, Agustus 2014, ISSN: 0853-1269. Pusat Penelitian dan Pengabdian Masyarakat STIEYKPN Yogyakarta. diakses 07 November 2017

Kamaliah Dkk, Analisis Pengaruh Rasio Aktivitas, Leverage Keuangan, Ukuran Dan Umur Perusahaan Terhadap Profitabilitas Perusahaan Wholesale And Retail Trade Yang Terdaftar di Bursa Efek Indonesia, (Jurnal Ekonomi, Universitas Riau, Vol. 17 No. 3, 2009).https://ejournal.unri.ac.id/ index.php/ JE/ article/ view/731

Khan, Arifur and Muttakin, Mohammad and Siddiqui, Javed, Corporate Governance and Corporate Social Responsibility disclosures: Evidence from an Emerging Economy (May 4, 2012). Journal of Business Ethics, 2012. Available at SSRN: https:// ssrn.com/abstract=2051064

Kolk, Ans and Pinkse, Jonatan, The Integration of Corporate Governance in Corporate Social Responsibility disclosures (February 28, 2009). Corporate Social Responsibility and Environmental Management, Vol. 17, No. 1, pp. 15-26, 2010. Available at SSRN: https://ssrn.com/abstract $=1350939$

Lindiasari, Palupi dan Sri Undartik, Analisis Profitabilitas Bank Umum Go Public di Indonesia Sebelum dan sesudah Krisis: Faktor Internal dan Eksternal, (Jurnal Ekonomi Kuantitatif Terapan, Universitas Indonesia, Vol. 8 No. 2, 2015).https://

ojs.unud.ac.id/index.php/jekt/article/download/16512/10808

Masrurroh, Dewi Ayou dan Ade Sofyan, Analisis pengaruh size perusahaan, Capital Adequacy Ratio (CAR), Non Performing Financing (NPF), Return on Asset (ROA), Financing to Deposit Ratio (FDR) terhadap pengungkapan Corporate Social responsibility (CSR) BUS di Indonesia periode 2012-2015. Human Falah: Vol 4. No. 1, 2017.

Matthew J. Kotchen dan Jon Jungbien Moon, "Corporate Social Responsibility for Irresponsibility"NBER Working Paper No. w17254. (July 2011).

Othman, Rohana, AzlanMdThani dan erlane K Ghani (2009), "Determints of islamic social reporting Among Top shariah-approved Comapnies in Bursa malaysia" Research Journal of International Studies Issue 12 oktober, 2009 https://www.researchgate.net/profile/Rohana_Othman/publication/22 8783690_Determinants_of_Islamic_Social_Reporting_Among_Top_Shar i\%27a-Approved_Companies_ in_Bursa_

Malaysia/ 
Muhammad Sultan Mubarok

links/5552c44e08aeaaff3bf00119/Determinants-of-Islamic-SocialReporting-Among-Top-Sharia-Approved-Companies-in-BursaMalaysia.pdf

Pernyataan Standar Akuntansi Keuangan (PSAK) No. 101 tahun 2007 tentang penyajian laporan keuangan syariah. h. 101.12. https:// abufadilah. files. wordpress. com/2011/07/psak-101.pdf

Prasanjaya, Yogi dan I wayanRamantha, Analisis pengaruh rasio CAR, BOPO, LDR, dan Ukuran perusahaan terhadap profitabilitas bank yang terdaftar di BEl, (E-jurnal Akuntansi Universitas Udayana, Vol 4.1, 2013). https://ojs.unud.ac.id/ index.php/ Akuntansi/ article/view/5912

Putri, Tria Karina. Etna Nur AfriYuyetta, "Faktor-Faktor Yang Mempengaruhi Islamic Social Reporting Perusahaan-Perusahaan Yang Terdaftar Pada Indeks Saham Syariah Indonesia (ISSI) Tahun 2011-2012" . (2014) : diponegoro Journal Of Accounting, vol 3 no 2 tahun 2014, ISSN (Online) : 2337-3806. Semarang. diakses 07 November 2017 http://ejournals1.undip.ac.id/index.php/accounting

Rama, Ali . "Analisis Determinan Pengungkapan Islamic Social Reporting: Studi Kasus Bank Umum Syariah di Indonesia". (2014):EQUILIBRIUM: Jurnal Ekonomi Syariah, Vol. 2, No.1,

Raza, Ali et al.,Relationship between corporate social Responsibility (CSR) and corporate Financial Performance (CFP): Literature review approach, Elixir Fin. Mgmt. 46 , 2012 http:// www. elixirpublishers.com/articles/1351163487_46\%20(2012)\%2084048409.pdf

Rifai, Moh. dkk., pengaruh ukuran perusahaan, struktur modal dan pertumbuhan perusahaan terhadap profitabilitas studi pada perusahaan manufaktur di BEl tahun 2010-2012, (Jurnal Universitas Pandanaran Semarang, 2015).https://jurnal. unpand. ac.id/ index.php/AKS/article/view/333

Roziq, Ahamd dan HerdianNisarDanurwenda, "Pengaruh Good Corporate Governance Terhadap Corporate Social Responsibility Melalui Risiko Bisnis Dan Kinerja Keuangan Pada Bank Umu Syariah di Indonesia". (201): Jurnal Ilmiah. Program Studi Akuntansi Fakultas Ekonomi Universitas Jember. diakses 07 November 2017

Rubin, et.al.,"Corporate Social Responsibility as a Conflict between Shareholder"s (March 10, 2006). EFA 2006 Zurich Meetings. diakses 28 
The determinants of Islamic social reporting disclosure....

Januari 2018. Available at SSRN: https://ssrn.com/abstract $=686606$ or http://dx.doi.org/10.2139/ssrn.686606

Rusmawati Dj, Yunni. Pengaruh Ukuran Perusahaan, Struktur Hutang, Dan Umur Perusahaan Terhadap Profitabilitas Pada Perusahaan Food \&Beveragesdi Bursa Efek Indonesia Tahun 2012-2014, ( Jurnal Penelitian Ekonomi Dan Akuntansi, Vol. I No. 2, 2016).journal.unisla.ac.id/pdf/114122016/4.\%20bu\%20\%20yuni.pdf

Sembiring,Eddy Rismanda. karakteristik perusahaan dan pengungkapan tanggung jawab sosial: studi empiris pada perusahaan yang tercatat di bursa efek jakarta. Undip: MAKSI, 6 . ISSN 1412-6680. http://eprints.undip.ac.id/ 35124/1/ JMAKSI_ Jan_ 2006_ 05_ Edy_Rismanda_Sembiring.pdf

Solikhah, Badingatus, An Overview of Legitimacy Theory on the Influence of Company Size and Industry Sensitivity towards CSR disclosure (May 3, 2016). International Journal of Applied Business and Economic Research (IJABER). Vol. 14, No. 5, p. 3013-3023, 2016. Available at SSRN: https://ssrn. com/ abstract=2893283

Syakti, Yosefa dan LundovicusSensiWondabio, Pengaruh CSR disclosure Terhadap Earing Response Coefficient, UnhasMakasar: Simposium Nasional Akuntansi $\quad$ X, 2007. http://staff.ui.ac.id/system/files/users/ludovicus.sensi/publication/akp m-08.pdf

Totok Dewayanto, " Pengaruh mekanisme GCG terhadap kinerja perbankan nasional", fokus ekonomi, Vol.5, No2. 2010

Yamin, Sofyan dan Heri kurniawan. "Structural Equation Modeling". Jakarta: Salemba Infotek, 2009.

YanuardiAlindra dkk., Faktor Determinan atas Profitabilitas Perbankan Yang Terdaftar di Bursa Efek Indonesia, (Jurnal Akuntansi Multiparadigma, Universitas Brawijaya Malang, Vol. 5 No. 2, 2014).http://jamal.ub.ac.id/index.php/ jamal/article/ download/ 301/352

Yusuf, M. Yasir dan Wan Sri Mahriana, Faktor-faktor yang mempengaruhi tingkat profitabilitas bank pembiayaan rakyat syariah (BPRS) di Aceh, (IQTISHADIA Vol. 9, No.2, 2016).http://journal.stainkudus.ac.id/index.php/IQTISHADIA/article/vie w/1731 
Muhammad Sultan Mubarok

Yusuf, Muhammad Yasir. "Islamic Corporate Social Responsibility( I-CSR) pada lembaga keuangan syariah: teori dan praktik". Depok: Kencana, 2017.

\section{JIEMB | 172}

